\title{
Violence as an Expression of Energy ${ }^{1}$
}

\section{Introduction}

The French novelist Donatien-Alphonse-François de Sade's (1740-1814) last request was that acorns should be sewn onto his tomb. He did not want his name or his literary works to be remembered by those who came after him. Soon after his death in 1814 , however, it was clear that his wish would not come true: the eponym 'sadism' appeared in the Dictionnaire universel de la langue française in 1834; eminent writers such as Charles Baudelaire and Gustave Flaubert discussed his novels; at the end of the $19^{\text {th }}$ century, Sade's name appeared in a totally new context, namely in psychiatry; and last but not least, Sade was an important figure for the surrealists, who saw him as an intellectual companion in their revolt against bourgeois society.

Despite this multi-faceted interest in Sade, however, the Marquis' novels were not interpreted and discussed thoroughly for more than 150 years. This changed, however, in the two decades after the Second World War, when his work became the central focus point for most of the French leading philosophers of that time: Pierre Klossowski, Simone de Beauvoir, Maurice Blanchot, Roland Barthes, Michel Foucault, Jacques Lacan, and Gilles Deleuze. Although these philosophers did not, of course, share all their interests, we can be sure of at least one thing, namely that they have read and studied the work of 'the divine Marquis de Sade' thoroughly, as he was once called by the French writer and poet Guillaume Apollinaire.

Among them was also Georges Bataille, who became part of the postwar group of philosophical Sade interpreters, when on May 12 1947, he gave a talk at a conference at the College Philosophique, titled 'Le mal dans le platonism et dans le sadism'. ${ }^{2}$ Later on, Bataille published 
several other texts on Sade: 'Le secret de Sade' and 'Le secret de Sade (II) ${ }^{3}$; 'Sade' ${ }^{4}$; 'Le bonheur, l'érotisme et la littérature (II) '5; 'L'homme souverain de Sade' ${ }^{6}$; and 'Sade et l'homme normal ${ }^{7}$. In those studies Bataille repeatedly comes back to one specific theme. Indeed, he draws attention, just as almost all French Sade interpreters of his time do, to the libertines' apathy, which means that Sade's characters lean on at an important and well-known philosophical tradition, namely the Stoics from ancient Greece. Therefore, one cannot argue, at least not from Bataille's point of view, that Clairwil, a character from Juliette, is Sade's true hero. Indeed, when she kills, she has a twinkle in her eye and a blush in her cheeks. She is too enthusiastic, according to Bataille, to be an example of a true Sadean hero. In real libertinism, on the contrary, no trace of passionate emotion can be found. Sade's libertines are apathetic, and it is precisely to this apathy that their enjoyment is related. Thus, whenever Juliette takes pleasure in killing, her enjoyment, as Bataille argues, has to be understood as an apathetic kind of enjoyment.

In secondary literature, however, one can hardly find scholars that focus on the sadist's apathetic enjoyment, as it is interpreted by Bataille. ${ }^{8}$ Therefore, the goal of this article is to gain an understanding of Bataille's intriguing interpretation of the sadist's apathetic enjoyment. The text is structured as follows. I first look at the way in which we need to understand Sade's apathy, irrespective of Bataille's own technical vocabulary. I then sketch his framework comprehensively, since in the third part it will become clear that Bataille conceives Sade's apathy in relation to that particular framework. Based upon both the outline of Bataille's theoretical framework and his findings on Sade's works, we will be able to point out what the differences and similarities are between apathy in Sade and stoic apathy. In the fourth and fifth section, I clarify Bataille's notion of sadistic enjoyment, showing that this kind of enjoyment is quite similar to mystical enjoyment and showing that transgression takes an important place in 
the sadist's enjoyment, albeit not in its moral but rather in its metaphysical form. Finally, in the conclusion, I formulate two theses, which can be the starting point for further philosophical research.

\section{Apathy and Involvement}

When we first have a look at the way people behave normally we see that they are interested in the vicissitudes, the welfare, and the happiness of others, implying, among other things, that one assesses whether or not his acts will be harmful to others. In normal life, one takes into account the possibility that he will not be able to continue his behavior unhindered. If the behavior is harmful to others, he will in fact change, slow down, or stop that behavior. This personal involvement with others is also expressed in what Peter Strawson once called an 'emotionally reactive attitude', which means that people react and respond to the other's

emotions. In concrete terms: people feel pity when their actions have harmful or hurtful consequences for others.

In ordinary life, however, one is not only involved with the other, but also with oneself, which becomes clear if we look at some of the emotions that arise spontaneously in our lives. Indeed, a large part of our emotions cannot be understood without looking at the attachment we have to our 'self', in the broadest sense of the word. Such is the case, for example, with the shame of our own brute nakedness, the fear of an imminent danger, or the distress resulting from a narcissistic injury by a friend. This self-involvement is not only reflected in our emotions but also in our behavior. Here, at least two aspects can be distinguished. First, people often have a personal connection with their action, meaning that human beings are involved in what they do and that they express via that involvement their preferences. Second, persons are not only 
sensitive to the consequences of their actions for themselves, they often act because of the positive impact that these actions have on themselves. This implies that self-involvement can also have an inhibitory effect on action. If the consequences prove to be detrimental, then the action will be adjusted or stopped altogether.

Things work very differently in Sade's literature. When we look at his libertines, it appears, as Bataille rightly observes, that they are insensitive to, or do not take into account the sorrow, the pain, or the fear of others. ${ }^{9}$ In Juliette, for example, we read the following: "If after you have done calculating you end by approving, as I am very sure you shall, the extinction of all sensibility in a pupil, then the first branch to lop off the tree is necessarily pity." 10 Apathy in Sade, however, does not only entail that the sadist has no emotionally reactive attitudes or that he is simply insensitive to the suffering of the other. His insensitivity has deeper roots; his absence of emotion is an expression of something more fundamental. More specifically, Bataille argues that the sadist is characterized primarily by what he calls the sadist's 'unicism' or 'absolute solitude'. This attribution should not be taken to imply that the sadist possesses a trait that others lack. Bataille rather refers to the fact that the sadist is in no way related to the other and that he does not participate in the interpersonal circuit in which people are interested in each other. In short, one of the central features of Sade's world, according to Bataille, is the absence of a link with others.

Bataille stresses, however, that the sadist is characterized not only by the lack of commitment to the other but also by any form of self-involvement. ${ }^{11}$ Sade's apathetic libertines do not just abandon their sympathy but also break away from emotions such as fear, shame, and sadness that often spontaneously take the upper hand and that express a commitment to the self. This destruction of self-involvement also means that the sadist does not have the two aforementioned 
aspects of self-involvement. First, personal preferences are completely destroyed in Sade's world. For example, while a heterosexual libertine might prefer a slender red-haired woman when not in the company of other libertines, this preference falls away as soon as he is in their company. From that moment on, anybody can satisfy his sexual desires: relatives, clothes, shoes, animals, etc. Furthermore, the sadist is in no way interested in the consequences of his actions for himself. Although he is fully aware of the consequences when he continues his atrocities (he will be put in jail), this does not deter him from further killing and torture. Nor is it true that the sadist commits crimes because this would bring him some kind of future benefit or advantage. In short, the sadist is not involved in what he does and does not focus on what is good in terms of his own self-interest.

\section{General and Restricted Economy}

Before we can fully understand the apathy, we must look at Bataille's own specific vocabulary, which he developed during the 30s and 40s, and which provides the background against which he interprets Sade's works. ${ }^{12}$ This framework is dualistic, in the sense that existence can be separated into two systems each operating according to a different economy: on the one hand, the secular order which functions according to what he calls 'the limited economy'; on the other hand, the sacred order following the logic of 'the general economy' ${ }^{13}$ How does Bataille understand the secular world, where daily life takes place, and the sacred order, to which one enters only exceptionally? ${ }^{14}$

Bataille regularly refers to the Paleolithic or the Old Stone Age. This is not only because it was in this period that funeral rituals and the first forms of art arose, but also, and above all, because it was in this period that the first durable tools were constructed. This making of instruments 
evolved in the course of history, and came to form the basis of secular life, meaning that this normal life needs to be thought of in terms of 'labor' and 'work', and that the man who lives this life came to be the homo faber. This implies that in ordinary life one relates to reality in a rather instrumental way: the things that are available and exist in the world, are always part of a chain of means leading to the production of an end. Take the example of metal being used in order to construct a hammer. In the next step, this hammer is used to transform some wood into a piece of furniture, for example a chair, which helps a human being to sit while, for example, reading the newspaper. This relation of means and ends has as its philosophical consequence that the value of something does not lie in the thing itself, but rather is derived from the purpose for which the thing is a tool. In other words: in the secular sphere, things have a meaning or value only insofar as they are instrumental.

This analysis does not mean that in the Paleolithic period people replaced a more basic relationship to reality with an instrumental relationship. After all, it is only when one begins to work that for the first time a relationship to reality is established. Thus, work introduces, above all, not an instrumental relationship, but a relationship to the world as such. This implies that during this period one breaks with a certain experience of reality. From that time on, reality is no longer perceived as a continuum in which no distinctions appear to exist and in which everything seems to overlap with something else. Indeed, when humanity begins to transform reality, a distance is installed and a line is drawn between the world on the one hand and those who work in it on the other. In other words: it is only with the secular sphere of work that man begins to experience himself as distinct from the world. Only when one begins to manufacture does one begin to experience oneself as an isolated or a 'discontinuous entity'. Moreover, the secular order remains as such to the extent that man can attribute a distinct ego to himself and so long as he is able to differentiate between himself and the world. 
According to Bataille, one does not need to conclude, however, that human existence should be reduced to this instrumental relationship or that it cannot take another posture in life. For the greater part of his life man may put the world at a distance and experience things in the world as distinct from himself, but that does not mean that this is the only possible way he can experience reality. Another possible experience of reality can be aroused by the way that animals experience it. Animals, Bataille holds, do not take a transcendent position in relation to the world and are not related to the world as discontinuous entities. The world of the animal is one in which everything seems to be superfluous and in which there seem to be no limits that separate bodies from each other. It is as if there is a fluid transition between the part and the whole, just as there seems to be no limit, to use one of Bataille's metaphors, between a drop of water and the sea: "Inevitably, before our eyes, the animal is in the world like water in water."15 Such an experience is not totally foreign to man, and can be aroused by the animal world, precisely because there, according to Bataille, boundaries are confused. In fact this leads man directly into a sphere that Bataille describes as 'sacred'. At such a holy moment man experiences a continuity between himself and the world that is accompanied by a suspension of the instrumental relationship to the world.

The framework just outlined is also translated by Bataille into an energetical terminology. ${ }^{16}$ The starting point is the observation that on earth a high quantity of energy is circulating that transcends the existence of man. That energy flows continuously in every human organism, meaning that man is at all times filled with energy he then invests in something else. He uses this energy, for example, for his productive activities or invests it in personal relations, i.e. the relation with himself and others. ${ }^{17}$ However, the amount of energy that is required for involvement in oneself and others is smaller than the available energy. Man always receives 
more energy than he invests in work, in himself, or in others. He thus contains an excess of energy which continues to grow incessantly. Because the production of energy never stops, there is a growing surplus that is not invested and that continues to be built up. This surplus is not used by anyone, but at the same time it would not be true to say that it has no effect. The extra energy leads to the growth of, for example, the human body or the many products resulting from labor. But this growth cannot be continued without limit. The increase is well suited to domesticate the excess, but that solution works only temporarily because growth is limited. The consequence is that the energy, because it continues to increase without being invested in something else, is built up until the moment that the boundary separating the person from the outside world breaks down. What follows, is an explosion of energy wherein the person disappears, and which is accompanied by the suspension of labor and any form of involvement.

The burst of energy is very different from the energy handled by man in secular life. While energy is normally directed towards the person himself or towards others and is used for work, the explosion of energy now leads to nothing. When the person's ego is overwhelmed by the flow of energy, this energy is not invested in anything else. From the limited human perspective, in which the emphasis is on involvement and the use of power, this stream of energy is merely waste and extravagance. The excessive energy that breaks through the limits of the person as a discontinuous entity is what Bataille calls la part maudite; it is the remainder that does not fit into the worldview of man since in this view energy is primarily invested in and used for something else. From a more general non-human perspective, however, the same phenomenon can also be approached in a positive way. Indeed, although the sacred experience means that boundaries are blurred and that the person's ego is lost (which is a negative description), that loss is an effect of the energy that crosses the border between the self and the world. In short, 
during a sacred experience, humans are driven by non-human energy that is first saved by the person and that then passes through him.

\section{Energy and Apathy}

In order to understand Bataille's Sade interpretation, we needed to outline his general framework. From now on we can focus on this interpretation, which often links the sexual cruelties in Sade with normal erotic behavior.

Bataille often refers to eroticism, which he argues has nothing to do with sexual reproduction. ${ }^{18}$ While sexual reproduction is about the creation of life, eroticism is linked to the death, in the sense that it causes the temporary disappearance of the person's ego and of the experience of a boundary between the person and the environment. ${ }^{19}$ Thus, eroticism is a sacred experience in which the transition from discontinuity to continuity takes place, a transition that is initiated by the act of undressing. This needs to be understood from the fact that the meaning of clothes is not reducible to their functionality. Clothes not only protect the body against the cold, they also highlight distinctions, which can be seen from the fact that several professions require a certain dress code or that some styles of clothes express the values of a social class. Thus, when someone is undressed, this causes the disappearance of interpersonal differences. Eroticism begins with observing the nudity that obliterates the differences and wherein the beloved, as Bataille says, 'is sinking into a void' and 'loses himself in the nothingness of death' ${ }^{20}$ This arouses in others the desire to take off their own clothes and to lose themselves in a movement that ends in what the French call 'la petite mort'. Formulated in Bataille's terms: the erotic experience is a burst of energy in which the person's ego is dissolved, and that is not directed at a goal. 
It is precisely upon these ideas that Bataille's Sade reading is based, which makes clear that the sadist does not really break with normal eroticism. Certainly, it is the case that the relationship between sadist and victim differs at several levels from the relationship between lovers. However, the differences are not of such a nature that we can speak of a radical break between the two. Although the tableaux vivants seem to be totally different from what we know in normal life, Bataille argues that Sade is in line with the sacred erotic experience. ${ }^{21}$ This means that we must also understand Sade's apathy from a 'general perspective'. In what sense?

Above we have seen that the removal of clothes takes away what makes the other person unique and leads to an experience of continuity. When the sadist abuses his victim, those atrocities have the same effect. Via extreme violence, just as with the act of undressing, the discontinuity of the other disappears. ${ }^{22}$ More specifically, the discontinuity disappears, according to Bataille, by the fact that severe pain is expressed in the face of the victim. ${ }^{23}$ With the cry of the victim, the mouth is opened widely, and the face is contorted in a tense and strained expression. The result of that spastic cramp is that those aspects of the face that distinguish the individual - the color of the eyes, the size of the nose, or the shape of the lips - fade into the background. With the contraction of the facial muscles, the traces of the other begin to disappear. Therefore, severe pain, just like nakedness, destroys the discontinuity of the person. Normally people are recognized and distinguished on the basis of some particular facial features, but when someone suffers violently those features fade away, and the individual disappears in the dark night of pure anonymity.

So too in the case of the sadist, the contemplation of the destruction of discontinuity leads to an experience of continuity. When the other disappears in pain, a violent move is triggered that 
ends in the mortification of the sadist's uniqueness. Formulated more precisely, the intense pain of the other and the loss of the self cause a stream of energy in which the boundary between the ego of the sadist and the outside world disappear. ${ }^{24}$ It is exactly at this point, as an effect of observing the continuity of the other, that Bataille situates Sadean apathy. As we have seen before, this apathy breaks with the attitude of personal involvement, meaning that no energy will be invested in oneself or in others. This does not mean, however, that the energy as such disappears. No, the energy is disconnected from any kind of involvement, which means that a large amount of energy can be accumulated. ${ }^{25}$ When the other as a discontinuous entity disappears in pain, then the energy, which was hitherto invested in the ego and in others, is no longer bound; it becomes a large quantum of energy putting the sadist's ego under pressure. When finally the person can no longer hold the pressure, they disappear in an explosion of energy, and the boundary that separates the sadist from the outside world implodes: "The desire of the senses is the desire, if not to destroy oneself, to burn at least and to lose oneself without reserve." ${ }^{26}$ That sacred experience of continuity is the outcome of a flow of non-human energy that breaks into human existence and for which the sadist is nothing but a vehicle.

Based upon this analysis, we can determine in what sense this conception of apathy differs from or is similar to the apathy of stoicism. Indeed, as is it well known, apathy is not only central in Sade but also in the philosophical movement that flourished during the fourth and third century BC in Greece. First of all, it is important to notice that, in stoicism, apatheia is a moral ideal which is based on a cosmology. The stoic apathy needs to be understood from a certain conception of the universe, a conception that sees the universe as optimally rationally ordered by God. Although human reality is often chaotic or the product of mere coincidence, the cosmos is totally rational. The highest good then, which leads to happiness, is that man lives in accordance with this rationally ordered cosmos, meaning that he structures his life following 
the rational lines in the non-human universe. This view implies that man is morally virtuous only if he makes his choices based solely upon a power which God gave to humanity: reason. The moral good, in other words, lies only in man, namely in his rational mind. It follows then that emotions, which are seen by the Stoics as the opposite of reason, fall under the heading of moral evil. Indeed, according to stoicism, emotions arise when a value is attributed to affairs that are external to the human mind, and that, thus, are actually morally indifferent. In other words, whoever is angry because his money has been stolen, makes a moral mistake. The reason is that he is then determined by externals which have no moral value. He would only be morally virtuous if he were left untouched by the loss of his money. In short, apathy is a necessary condition for moral virtue. The one who reaches that state of mind, and so only uses reason, is good in a moral sense and lives in accordance with the cosmos.

We can conclude that stoic apathy is embedded in a broader perspective, since the one who is not affected by morally neutral external things, is tailored to the rationally ordered cosmos. This means that the life of the Stoic is consistent with what transcends human life, which is also the case for the Sadean character. Indeed, when the energy, which in normal life is invested in the self or in the other, is not so invested and instead goes through the sadist, then the sadist is in fact obsessed by a stream of non-human energy that transcends the 'limited' human life.

Despite this similarity, however, one can perceive at least four differences. The first difference is that apathy in Stoicism is a moral ideal, while the Sadean apathy does not have a moral meaning, at least not in Bataille's analysis. Within the perspective from which Bataille reads Sade, the apathetic sadist does not incarnate the highest good. Just like eroticism, he is nothing but an illustration of a reality that falls out of ordinary life and that, seen from the viewpoint of l'économie restreinte, is pure waste. Second, for Sade, unlike for the Stoics, apathy is not a 
goal, as the sadist does not explicitly aim at the destruction of personal involvement. The fact that this attitude is destroyed, is rather an effect of the fact that the sadist perceives that the other disappears in pain. This experience of continuity fuels the energy that then both breaks away from any kind of personal involvement and triggers a cruel movement wherein the sadist's ego will be dissolved. The third difference lies in the fact that in Stoicism the extension of the concept of apathy is larger than in Sade's case. While the concept of stoic apatheia refers to something that breaks with any externality: body, money, property, etc., the concept of Sadean apathy refers only to the destruction of any kind of personal involvement. Fourth, other than in Stoicism, the sadist is not characterized by the use of the capacity of reason, but by the fact that he is overwhelmed by an energy, which has as its consequence the destruction of any capacity of rational thinking.

\section{Sadistic and Mystical Enjoyment}

According to Bataille, sadism and the activity of undressing have in common the destruction of the discontinuity of the other. This means that the sadist enlarges what is present in eroticism but what at the same time stays in the background, namely the fact that eroticism is associated with violence. Both also share the idea that the destruction releases an amount of energy, that of itself is not involved in anything else beyond itself. The energy occupies neither the ego nor the other, and does not focus on a preconceived telos. In the ordinary erotic experience man lives in accordance with this energy. Therefore, eroticism can be described as an expression of a non-human and aimless energy in which the person's ego is dissolved and which is not directed at a future goal. 
The sadist also lives fully from that stream of energy. The emphasis, however, lies not on the fact that the cruel actions lead to nothing. The sadist is characterized primarily by the fact that she is not hindered by emotions, such as remorse, that would betray a personal involvement. Therefore, it is not merely that a quantum of energy forms in the sadist that overwhelms him and dissolves his ego, it is also that that energy feeds - following the title of one of Bataille's Sade studies, namely un érotisme sans limite - a way of acting that can continue unperturbed, immune to hindrance from any form of involvement. ${ }^{27}$ Put in other words: impersonal energy is expressed in the uninhibited series of crimes. ${ }^{28}$ This implies that the sadist's activities are not based upon the sadist's will. The sadist's cruel act is an act without ego and the expression or conductor of non-human energy. This is echoed in the following passage from Juliette: "But were one really to wish to persuade oneself that this talk about freedom is all empty prattle and that we are driven to whatever we do by a force more puissant than ourselves [...]." 29

We can thus hold that Bataille understands Sadean apathy not only in a negative way but also in positive terms: negatively spoken, apathy is an effect of energy that detaches itself from any form of personal involvement; positively, apathy is the expression of a force that continues imperturbably. Furthermore, it appears that, according to Bataille, a turnaround can be perceived. While the collection of energy first is the effect of the crime, the apathetic crimes then become an expression of a large quantity of impersonal energy. The sadist is thus not only characterized by the accumulation and explosion of energy that no longer circulates within the secular order. Due to the uninhibited concatenation of crimes the sadist also lives truly from the flux of non-human energy that breaks down in its pure form into the human condition, and thus deforms that condition into something non-human, in the sense that it transcends human characteristics. 
Bataille holds that the sadist's enjoyment is rooted in the latter. ${ }^{30}$ Sadistic enjoyment follows from the fact that the apathetic sadist lives in accordance with the impersonal energy. The sadist enjoys the fact that his actions express the power of energy that transcends ordinary life and that, seen from the viewpoint of l'économie restreinte, is nothing but pure waste. In other words, the sadist's enjoyment is an effect of the fact that via his cruel deeds he is geared to l'économie générale according to which energy circulates freely and is not invested in something other than itself. Thus, sadistic enjoyment has nothing to do with pleasant sensation. ${ }^{31}$ Indeed, that sensation presupposes immediate self-involvement - the sensations are always mine -, while the sadist suspends any form of personal involvement. It also follows from Bataille's reasoning that it is not true that the sadist enjoys looking at the pain of others or that he likes to inflict pain on others. Indeed, if he would enjoy the other's pain, then this would imply that the sadist, although in a negative way, still depends on the other. This cannot be the case, however, as the sadist is characterized by apathy.

Sade's apathetic enjoyment seems to be a special kind of enjoyment. Bataille, however, suggests that the sadist's enjoyment is similar to at least one other type of enjoyment, since he connects the sadist with the mystic at least twice. ${ }^{32}$ This suggests that Bataille sees a link between sadistic and mystical enjoyment. How ought we to understand this?

Hermits are not characterized by the will to converse with others. They don't travel around the world to convince others of the idea that mankind was created by God and that man is part of a divine plan of salvation. Nor do they want to save the world or try to purify the world from evil. Mystics don't travel around the world but withdraw and separate themselves from the world. They live isolated in monasteries where they get rid of their personal interests and ambitions via intensive prayer and meditation. Although mysticism cannot be reduced to this 
negative attitude, a mystical life begins with discipline. This first stage can also be described in a positive way, since the emptying of self and of the world is supported by a love for God and by an intense desire for union with God. The fact that the mystic breaks with his individual life and with the world must be understood in terms of the upward movement to God as the object of desire.

However, the mystic is not continuously stirred up by his desire. The mystical life is interrupted, sometimes for a long time, by periods in which the love of God fades away. If that is the case, what then comes to the fore is what was first nothing but a step towards union with God, namely the annihilation of the self and the world. When the focus on God is lost, the mystic falls back into a world in which nothing touches him and in which all life is drawn away from the normal way of being, just as in Hegel's night where 'all cows are black'. This period is accompanied by a destruction of the will: the mystic no longer has personal goals and destroys all sorts of desires. In that phase, known as 'the dark night of mystical suffering', the emptying of the self and the world leads to apathy. Every force has left the mystic, which means that in the end he is unable to act.

In the final stage, one can perceive a union with God, meaning that the mystic disappears as a person and becomes the expression of a divine force that lives through him. This unification has as its effect the transcendence of the mystic's apathy, the state that had characterized the mystic after losing his desire for God. Thus, on the final stage of the mystical road, the apathy disappears. The mystic is taken away from his depressive state, and this is made possible by the divine power that expresses itself in him. God expresses himself in the mystic, and this incarnation throws the mystic back into the world. God's expression in the mystic is the cause of the fact that the mystic starts working and living again. That worldly behavior, however, 
breaks with the sorts of actions that characterize normal life. Indeed, the mystic's actions are no longer driven by personal goals and are no longer affected by what is happening in the profane world. In other words: when the mystic acts, it is as if he slides indifferently over things in a movement that leads to nothing.

It is precisely this unification with God and the apathetic actions resulting from the expression of God in the mystic, that arouse the mystics' enjoyment. According to Bataille, mystical enjoyment is an effect of the fact that the mystic's behavior is an expression of the divine power in him. On this basis, we can now understand the twofold similarity Bataille perceives between Sadean enjoyment on the one hand, and mystical enjoyment on the other. First, in both cases, enjoyment is not a goal, as is often the case in everyday life. Both Sadean and mystical enjoyment are rather a non-intended effect of something else. Second, and more specific, we can see that the mystic and sadist are similar regarding the cause of their enjoyment, since both enjoy the unification with a non-human force that is expressed in humanity.

\section{Enjoying Transgression?}

In ordinary life, people judge each other's actions, attitudes, and statements on the basis of, among other things, moral categories, namely the distinction between good and evil. Nothing of what happens in Sade's world falls under what we understand as good. The Sadean universe is on the other side of the moral boundary. Based upon another finding, that the experience of enjoyment is the only 'inner experience' which the sadist reports, it is not unlikely that some will find sadistic enjoyment to be about the transgression of the moral law. Because the sadist continually behaves in an immoral way and also never seems to stop enjoying, it should not be surprising that some conclude that what the sadist really enjoys is exceeding the moral 
boundary. Sadistic enjoyment, following a popular understanding, is all about enjoying radical evil.

One would expect this interpretation to return in Bataille's Sade studies. After all, the term 'transgression' is a basic concept in his thinking. To see this does not require a thorough study of his entire oeuvre; it is enough to take a quick glance at that oeuvre and to browse through Bataille's books quickly. For example, whoever opens L'érotisme sees that the title of the first theoretical part is called 'L'interdit et la transgression' and reads in the introduction that, according to Bataille, we should think of eroticism as a transgression. ${ }^{33}$ It is therefore not surprising that the introductions to, and commentaries on, Bataille's work often circulate around the notion of transgression. This is the case, for example, in the famous study that Foucault wrote about Bataille in 1963, one year after Bataille's death, whose title is 'Préface à la trangression'. ${ }^{34}$ Therefore, it is not surprising that in studies referring to his work Bataille is often presented as the 'philosopher of transgression'.

Based upon these findings, one might expect that in Bataille's Sade studies the term 'transgression' would be used repeatedly or that he would understand Sade's characters' enjoyment as related immediately to transgression. From what we have seen in the preceding paragraphs, however, this does not seem to be the case. Also, in none of his texts on Sade does Bataille regularly employ the term 'transgression'. From this point of view, it is somewhat surprising that, on the last pages of both 'L'homme souverain de Sade' and 'Sade et l'homme normal', he refers, either explicitly or implicitly, to transgression. ${ }^{35}$ With this reference Bataille indicates that he does interpret Sade's work with the help of the notion of 'transgression'. How should we understand this? What is the connection between transgression and sadistic enjoyment? 
In the previous sections we have seen that it is not pain as such that has an effect on the sadist, but what is happening in the pain, namely the destruction of discontinuity. That destruction, Bataille maintains, raises a desire for continuity and self-loss. Formulated more specifically, the loss of the self of the other causes the accumulation of a large amount of free energy in which the person's ego is dissolved. The sadist, however, is not only characterized by this accumulation of energy. That energy also expresses itself in the cruel acts, which are not inhibited by any form of involvement. The sadist is an expression of free and unbound energy which by itself is not aimed at anything other than itself. As we have seen, from the 'limited' perspective, in which energy is normally bound, that behavior is merely waste, but from the perspective of general economy, on the other hand, the apathetic act indicated that the sadist lives in harmony with the free energy.

It is precisely from that distinction between the 'limited' and 'general' economy that transgression in Sade must be understood. Thus, in the dualistic framework in which Bataille reads Sade, the emphasis is not on exceeding the moral boundary. Bataille's interpretation does not turn around crossing the boundary between moral good and evil. However, that does not mean that Bataille reads Sade without using the notion of transgression. Bataille does understand Sade from the notion of transgression, but the border that is exceeded by the sadist is a boundary that erases the moral distinction, namely the difference between the human and the non-human. Indeed, if the sadist is not hindered by any form of personal involvement, then he exceeds the 'limited' human perspective in which people are involved in themselves and thus lives in accordance with the non-human energy. This means that Bataille also understands sadistic enjoyment in terms of 'transgression', since the sadist's enjoyment arose from his alignment with the non-human flux of energy. This enables us to conclude that the sadist, 
according to Bataille, does not so much enjoy the transgression of the moral law, as most Sade readers believe. If Bataille's provocative interpretation of the famous libertine writer is correct, then the sadist rather enjoys the metaphysical transgression of the 'limited' perspective from which life is normally understood. ${ }^{36}$

\section{Concluding Remarks}

Based upon the foregoing paragraphs we can end with two remarks. While the first is about the reason why Bataille was interested in Sade, the second relates Bataille's analysis to the intellectual and philosophical context to which Bataille and his contemporaries belonged.

Almost all the concepts from Bataille's binary thinking can be deduced from the tension between what he calls 'the profane order' and 'the sacred order'. With the first order he refers to the ordinary life in which man is concerned about his self-preservation, develops a morality, is productive, is aimed at controlling reality, etc. The sacred order includes some rather rare activities, experiences and figures that put the familiar world in a state of disarray. More precisely and expressed in Bataille's energetic terms: the sacred order stands for that part of reality in which energy breaks into in a pure non-human form. It is that area au-delà the ordinary life in which Bataille's is interested and which he thematizes in his texts. That interest also led him to a figure like Sade. More specifically, he is fascinated by the apathy of the characters who inhabit Sade's literary world. After all, this apathy expresses a reality that transcends the profane order and that cannot be explained by the terms with which ordinary life is mapped out. Therefore, the first remark that is based upon what has been described in the forgoing paragraphs is that Bataille's interest in Sade has to do with the fact that his erotic literature reflects the theme of 'transgression', in the sense of exceeding the 'limited' perspective. 
The second remark has to do with the history of Western philosophy. In what sense? As is wellknown, modern philosophy places man at the heart of our concerns. This is one of the distinctions between modern and classical philosophy. After all, in premodern times, it is not man but God who is the center of reality: He created the world and He functioned as the center of man's thinking and acting. This means that in pre-modernity man is only the passive recipient of the knowledge and the law that God revealed to him. In modern philosophy, on the other hand, man occupied the sovereign position that used to be reserved for God. The basis of knowledge and action no longer was with Him, but with man. A typical example is the Copernican Revolution Kant caused in epistemological thinking. After all, according to Kant, knowledge is created by the human cognitive capacities that bring order to the sensory world. In his moral philosophy, too, Kant extends this turn to man. Moral action, according to Kant, does not obey a heteronomous, divine law but, on the basis of the autonomy of reason, springs from 'the moral law within me'. However, at the fore in Bataille's interpretation of Sade is the idea that man, in this case the sadist, as the sovereign subject of reality 'dies' and disappears from the center of reality. Marquis de Sade's characters are 'neither God nor master' over reality, but are subjected to and determined by the flux of energy that precedes their will, freedom or Ego. Therefore, Bataille's studies discussed above can also be read as an introduction to postmodernism through sadism. This is true as long as we understand postmodernism in a strict philosophical sense, meaning that man is not the center of the world and an expression of something else (language, energy, etc.), an idea that is also central in the thinking of, among others, Deleuze and Foucault.

\section{Bibliography}

Bataille, Georges. 'Le secret de Sade'. Critique 15-16 (1947): 147-60. 
Bataille Georges. 'Le secret de Sade (II)'. Critique 17 (1947): 304-12.

Bataille, Georges. 'Sade et la morale'. in La profondeur et le rythme. Troisième volume des Cahiers du Collège Philosophique (1948), 333-44.

Bataille, Georges. 'Le bonheur, l'érotisme et la littérature'. Critique 36 (1949): 401-11.

Bataille, Georges. 'Préface'. In Sade, D.A.F. De, Justine ou les malheurs de la vertu (Paris: Jean-Jacques Pauvert, 1954), VII-XXXVI.

Bataille, Georges. L’érotisme. Paris: Les Éditions de Minuit, 1957.

Bataille, Georges. 'Sade'. In La littérature et le mal, 120-48. Paris: Éditions Gallimard, 1957.

Bataille, Georges. 'L'homme souverain de Sade'. In L'érotisme, 183-96. Paris: Les Éditions de Minuit, 1957.

Bataille, Georges. 'Sade et l'homme normal'. In L'érotisme, 197-218. Paris: Les Éditions de Minuit, 1957.

Bataille, Georges. 'Le mal dans le platonisme et dans le sadisme'. In CEuvres complètes. Tome VII, 365-80. Paris: Éditions Gallimard, 1976.

Bataille, Georges. 'L'économie à la mesure de l'univers'. In CEuvres complètes. Tome VII, 916. Paris: Éditions Gallimard, 1976.

Bataille, Georges. 'La part maudite'. In Euvres complètes. Tome VII, 19-179. Paris: Éditions Gallimard, 1976).

Bataille, Georges. 'La limite de l'utile'. In CEuvres complètes. Tome VII, 185-280. Paris: Éditions Gallimard, 1976.

Bataille, Georges. 'Théorie de la religion'. In Euvres complètes. Tome VII, 281-361. Paris: Éditions Gallimard, 1976.

Bataille, Georges. 'L'Histoire de l'érotisme'. In CEuvres complètes. Tome VIII, 7-157. Paris: Éditions Gallimard, 1976. 
Bataille, Georges. 'Sade'. In Euvres complètes. Tome IX, 239-58. Paris: Éditions Gallimard, 1979.

Bataille, Georges. 'L'homme souverain de Sade'. In CEuvres complètes. Tome X, 164-75. Paris: Éditions Gallimard, 1987.

Bataille, Georges. 'Sade et l'homme normal'. In Euvres complètes. Tome X, 176-95. Paris: Éditions Gallimard, 1987.

Blanchot, Maurice. 'La raison de Sade'. In Sade et Restif de la Bretonne, 9-66. Bruxelles: Éditions Complexe, 1986.

Direk, Zeynep. 'Erotic experience and sexual difference in Bataille'. In Reading Bataille Now, ed. Shannon Winnubst, 94-116. Bloomington: Indiana University Press, 2007.

Guerlac, Suzanne. “ “Recognition” by a Woman!: A Reading of Bataille’s L'érotisme'. Yale French Studies 78 (1990): 90-105.

Hochroth, Lisa. 'The Scientific Imperative: Improductive Expenditure and Energeticism'. Configurations 3 (1995): 47-77.

Lauwaert, Lode. Maquis de Sade and Continental Philosophy. Edinburgh: Edinburgh University Press, 2019.

Marty, Éric. Pourquoi le XXe siècle a-t-il pris Sade au sérieux? Paris: Éditions du Seuil, 2011. Roche, Geoffrey. 'Black Sun: Bataille on Sade'. Janus Head 9 (2006): 157-80.

Stoekl, Allan. Bataille’s Peak. Energy, Religion, and Postsustainability. Minneapolis/London: University of Minnesota Press, 2007.

Sade, D.A.F. De. Juliette, of de voorspoed van de ondeugd. vert. H. Warren, Amsterdam: Ooievaar Pockethouse, 1995.

\section{References}

\footnotetext{
1 This is a revised version of the chapter on Bataille in my book on Sade.
} 
2 One year later, this text was published as 'Sade et la morale' in La profondeur et le rythme. Troisième volume des Cahiers du College Philosophique. See also Georges Bataille, 'Le mal dans le platonisme et dans le sadisme', 365380 and Id., 'Sade et la morale', 445-52.

${ }^{3}$ Id., 'Le secret de Sade', 147-60 and Id., 'Le secret de Sade (II)', 304-12.

${ }^{4}$ Id., 'Sade', 120-48. See also 'Sade' in CEuvres complètes. This text was based upon 'Le secret de Sade (II)'.

${ }^{5}$ Id., 'Le bonheur, l'érotisme et la littérature', 401-11.

${ }^{6}$ Id., 'L'homme souverain de Sade', 183-96. See also 'L'homme souverain de Sade' in CEuvres complètes. That text was based upon 'Le bonheur, l'érotisme et la littérature'.

${ }^{7}$ Id., 'Sade et l'homme normal', 197-218. See also 'Sade et l'homme normal' in CEuvres complètes. That article was first published as a foreword in Justine ou les malheurs de la vertu.

${ }^{8}$ See, for example, Geoffrey Roche, 'Black sun: Bataille on Sade', 157-80. One exception, however, is Éric Marty, Pourquoi le XXe siècle a-t-il pris Sade au sérieux?

${ }^{9}$ Georges Bataille, 'L'homme souverain de Sade', 167-8.

${ }^{10}$ D.A.F. De Sade, Juliette, of de voorspoed van de ondengd, 281; my translation.

${ }^{11}$ Georges Bataille, 'L'homme souverain de Sade', 174.

12 Ibid., 168-72.

${ }^{13}$ See also Allan Stoekl, Bataille's Peak. Energy, Religion, and Postsustainability, 3-31.

${ }^{14}$ These lines are based on Georges Bataille, 'Théorie de la religion', 281-345 and Id., 'L'érotisme', 33-145.

${ }^{15}$ Id., 'Théorie de la religion', 295; my translation.

${ }^{16}$ This is based upon Id., 'L'économie à la mesure de l'univers', 9-16; Id., 'La part maudite', 179; and Id., 'La limite de l'utile', 185-280. For a comprehensive discussion, see Lisa Hochroth, 'The Scientific Imperative: Improductive Expenditure and Energeticism', 47-77.

${ }_{17}$ Georges Bataille, 'L'homme souverain de Sade', 171. In this context, Bataille quotes from Blanchot's Sade study (Ibid., 171-2). For the passage that Bataille quotes, see Maurice Blanchot, 'La raison de Sade', 58-60.

${ }^{18}$ Georges Bataille, 'L'homme souverain de Sade', 169-70. See also Id., 'Le secret de Sade (II)', 308-9.

${ }^{19}$ See also Id., 'L'érotisme', 90-109.

20 Id., Le secret de Sade (II)', 308.

${ }^{21}$ Id., 'Le bonheur, l'érotisme et la littérature (II)', 407. See also Id., 'L'érotisme', 18.

22 Id., 'L'homme souverain de Sade', 170.

${ }^{23}$ Id., 'Le secret de Sade', 159.

${ }^{24}$ Id., 'Le secret de Sade (II)', 307.

${ }^{25}$ Id., 'L'homme souverain de Sade', 172.

${ }^{26}$ Id., 'L'Histoire de l'érotisme', 97.

27 Ibid., 173.

${ }^{28}$ In 'Kant with Sade' and his seminar on the ethics of psychoanalysis, Lacan also focuses on the endless repetition of the sadist's killing. However, while Bataille holds that the repetition is an effect of freed excessive energy, Lacan argues that the endless killing is due to the power of what he calls 'the symbolic order'.

${ }^{29}$ D.A.F. De Sade, Juliette, of de voorspoed van de ondengd, 14; my translation.

${ }^{30}$ Georges Bataille, 'L'homme souverain de Sade', 173.

${ }^{31}$ Ibid.; Id., 'Le secret de Sade (II)', 307.

${ }^{32}$ Id., 'Sade et la morale', 449-51.

33 Id., L'érotisme, 13.

${ }^{34}$ See also Zeynep Direk, 'Erotic experience and sexual difference in Bataille', 110, and Suzanne Guerlac, '

"Recognition" by a woman!: A reading of Bataille's L'érotisme', 90-2.

35 Georges Bataille, 'L'homme souverain de Sade', 174; Id., 'Sade et l'homme normal', 194-5.

${ }^{36}$ From what we have seen above, it appears that Bataille emphasizes the fact that the sadist exceeds a certain kind of boundary. In his Sade studies, he does not focus on, for example, the question of how the transgression and the boundary relate to each other. The latter is discussed elsewhere (see, for example, Id., L'erotisme, 66-72) and is rethought by Foucault later on in his text on Bataille titled 'Préface à la transgression'. 